\title{
To Access the Efficacy of Daivavyapashray Chikitsa-Chanting of Saurasukta on the Symptoms of Hypertension
}

Dr. Abhijit H Joshi"

Dean and HOD, Faculty of ayurveda, TMV, Pune, Acting Registrar, TMV, Pune, India

DOI: $10.36348 /$ SIJTCM.2019.v02i07.002

| Received: 10.09.2019 | Accepted: 18.09.2019| Published: 30.09.2019

*Corresponding author: Dr. Abhijit H Joshi

\section{Abstract}

Ayurveda as a complete life science describes the various treatment methods. Daivavyapashray chikitsa or no drug therapy is a form of treatment, roots of which can be traced up to the vedic era. Rugveda describes many verses useful in various health disorders. Rugveda samhita has mentioned Saurasukta in its first mandal, which praise the lord Sun to cure all cardiac problems and bestow the health. Ayurveda describes Hrudrog and its types, pathogenesis in detail. Hypertension is a condition which is the major cause of precipitation of cardiac diseases. The verse which cures heart disease is bound to cure the internal etiological factors for heart disease like hypertension.100 patients of primary hypertension was selected and divided in two groups. Patients in study group recited the the rugved rucha as per protocol and also given antihypertensive treatment. Control group patient received only antihypertensive treatment. The result were analysed after 90 days. After statistical analysis it is concluded that saura sukta chanting is proved as complementary module in the treatment of hypertension.

Keywords: Daivavyapashray, Saurasukta.

Copyright @ 2019: This is an open-access article distributed under the terms of the Creative Commons Attribution license which permits unrestricted use, distribution, and reproduction in any medium for non-commercial use (NonCommercial, or CC-BY-NC) provided the original author and source are credited.

\section{INTRODUCTION}

Ayurveda as a complete life science describes
various treatment modality. These includes
Daivavyapashray,Yuktivyapashray and satvavajay chikitsa[1].

\section{त्रिविधमौषधमिति- दैवव्यपाश्रयं, युक्तिव्यपाश्रयं, सत्त्वावजयश्च|} $\|\varphi<\|$

Daivavyapashray chikitsa includes use of various verses, medicinal herbs, devine stones, rituals etc. Yuktivyapashray chikitsa is a form of treatment which includes medicine in the form of tablets, decoctions, aasavas, arishtas, panchakarma therepies etc.

Satvavajy is a a form of treatment which focus on the satva or mind. Psycological disturbances often get reflected as physical disorders and many physical diseases has its origin in the pshycological imbalance.

Satvavajay chikitsa aims at strengthening of mind so that it can face or counteract with psychological and also physical disturbances. Out of these three forms,satvavajay chikitsa is being practiced since vedic era. daiva
Daiva-Is Destiny or outcome or the effect of ones karma

Karma- Is Physical. psycological,verb abuse(intentionally or unknowingly)

Daivavyapashray chikitsa-It aims at getting refuge from daiva or destiny. Hindu mythology believes that daiva is outcome of psycological,verbal,physical abuse or sins (intentionally or unknowingly).

Daiva or destiny is adrushta or cannot be identified.or seen. Aaccording to hindu mythology. Many physical diseases have its origin in the karma. Nidanparivarjan or avoiding the contact with of etiological factors is the main moto of ayurvedic chikitsa. To achieve this, one has to identify the cause of the disease.

Daivavyapashray chikitsa plays major role in such conditions where cause is unnoticed or has deeply rooted in karma. This type of treatment acts on the karma and nullifies it and thus the disease gets cured.

- तत्र दैवव्यपाश्रयंमत्त्रौषधिमणिमड्गलबबल्युपहारहोमनियमप्रायश्चित्तोपवास 
स्वस्त्ययनप्रणिपातगमनादि, युक्तिव्यपाश्रयंपुनराहारौषधद्रव्याणां योजना, सत्त्वावजय:पुनरहितेभ्योरर्थेक्यो मनोनिग्रहः॥४४\|

\section{- Tools of daivavyapashray chikitsa [3]}

- Mantra

- Aushadh

- Mani

- Mangal

- Bali

- Upahar

- Home

- Niyam

- Prayachitta

- Upavas swastyayan

- pranipat

- These are the tools of daivavyapashray chikitsa.

\section{Significan of daivavyapashray chikitsa[4]}

आशुव्याधिहरत्वेन- quick relief from disease. व्याधिप्रत्यनीकं-particular and disease specific treatment modality.

अदृष्टंहेतुप्रत्यनीकं-it acts on the un-noticed cause of disease.

Mantrachanting is one tool of daivavyapshray chikitsa.vedic literature esoecially rugved and atharvaved describes many verses for curing the diseases like heart disease, jaundice, respiratory disease and many more. saurasukta is one of such devine sukta of lord Sun.The rucha of this sukta praise the lord sun to cure the cardiac diseases and bestow with health [5]. Hypertension is one of the cheif reason inprecipoitation of cardias disease. Hypertension raised systolic pressure beyond $130 \mathrm{~mm}$ of $\mathrm{Hg}$ and syatolic blood pressure beyond $90 \mathrm{~mm}$ of $\mathrm{Hg}$.

Death rate of cardiac diseases due to hypertension is statistically high. The study is planned to observe the effect of chanting of mantra on hypertension. ayurveda do not describes primary hypertension but it has described Hrud-Rog in detail

Hrud Rog has 5 types such as vataj,pittaj,kaphaj,sannipatij and krimij[6]. Pittaj hrudrog Krodh is one of the causative factor of pittaj hrudrog and also it is one of the symptom [7]. Sweda is also one of the symptoms of hrudrog. Hence patients of hypertension are screened for the presence of these symptoms before and after treatment.

\section{AIMS AND OBJECTIVES}

Using saura sukta as a complementary module to manegment of primary hypertension, to reduce the symptoms of primary hypertension like sweda and krodha

\section{MATERIAL AND METHOD Sample size}

100 patients of Primary hypertension were included in the study.

\section{Inclusion criteria}

- $\quad$ Patients of Primary hypertension of age group 40 to 70 years

- Patient with informed consent

- Patients having faith in vedic knowledge

\section{Exclusion criteria}

- Patient with more than 70 years of age

- Female patients are excluded as the sutra chanting method do not allow the break of two to three consecutive days, and during menstruation female patients are not physically fit and there is chances of the gap in the chanting .

- Pregnant women

- Patients having ischemic heart diseases

- Patients who do not have faith in vedic knowledge.

\section{METHOD OF STUDY}

- 100 patients were selected by random sampling

- The patients were divided in 2 groups group A and group B

- Group A-The patients were trained for proper chanting of the specific ruche of saura sukta. Santha method was followed for and chanting was taught to the patients at holy places like temple or math. By the rugveda scholars. The time of chanting was decided to be in the morning one and half hour after sunrise.

Patients in this group were instructed for chanting the ruche for 28 repetitions once in a day at morning. The patients were taking the antihypertensive drugs prescribed by their physician.

- Group B- The patients were taking the antihypertensive drugs and not trained for saura sukta chanting. 


\section{Mantra}

\section{उद्यन्नद्य मित्रमह आरोहन्नुत्त्रां दिवम्। \\ हृद्रोगं ममं सूर्य हर्रिमाणं च नाशय।}

\section{ऋ.मं.1 अनुवाक् 9 सूक्त 50 ऋचा 11}

Lord surya, as you slowly rise in the sky as the progress of day, please abolish my cardiac disease and make me healthy.

\section{Mode of action of mantra}

Mantra is an invocation or a mystical formula, which aids the person to release the self and attain bliss and ultimate fulfillment. The sounds involved in a Mantra are themselves significant for they generate in the individual an unusual mystic power. Mantra produces a set of vibrations on the surrounding atmosphere \& its force depends on the attitude of the person as well as the intensity of concentration.

Mantras are performed though faith, the results of which cannot be analysed, measured, weighed seen but are felt. The force of Mantra can be only felt. It should be performed with due faith and all rituals. And then it is fruitful. One must have complete faith in Mantra he is reciting and must know its meaning.

i.e. $\mathrm{H}_{0}: \mathrm{P} 1=\mathrm{p} 2$ against an alternative

$$
\mathrm{H}_{1}: \mathrm{P} 1>\mathrm{p} 2
$$

Here $\mathrm{P}_{1}=31 / 50$ and and $\mathrm{Q}_{2}=5 / 50=0.1$ and hence $\mathrm{Q}_{1}=0.38$ and $\mathrm{Q}_{2}=0.9$

Thus $Z_{\text {calculated }}=6.4438$ and $Z_{\text {table }}=1.64$

Since $\mathrm{Z}_{\text {calculated }}>\mathrm{Z}_{\text {table }}$ we reject null hypothesis $\mathrm{H} 0$ at $5 \%$ level of significance

Hence the proportion of swed patients before treatment is greater than proportion of swed patients after treatment.

This shows that there is significant effect of treatment. This proves that at $95 \%$ level of confidence saura-sukta pathan is responsible for lowering swedpravartan as one of the symptom in all mild, moderate and severe grade primary hypertension.

\section{II) krodha}

$$
\begin{aligned}
& H_{0-} P_{1}=P_{2} \\
& H_{1} P_{1}>P_{2} \\
& \text { Here } P_{1}=40 / 50 \text { and } P_{2}=6 / 50=0.12 \text { and hence } Q_{1}=0.2 \text { and } Q_{2}=0.88 \\
& \text { Thus }
\end{aligned}
$$

Zcalculate $=9.329$ and $\mathrm{Ztable}=1.64$
Prescribed methods should be followed. The performer does experience sensation and vibrations during or at the end of Japa, this is a sufficient proof to believe. Mantra requires faith, Japa, hard work ad per laid dictums to realize the desired objects and vibrations. Each Mantra has a different use. The vibrations of sound create desired reactions within the body too.

\section{OBSERVATIONS \\ Statistical analysis of symptoms}

I) Sweda

$\mathrm{H}_{0}$ : There is no difference in the proportion of

$\mathrm{H}_{1}$ :-Praportion of swed patient before treatment is more than proportoion of swed patients after treatment. 
Since Zcalculate >Ztable we reject null hypothesis at 5\% level of significans hence the proportion of swed patients before treatment is greater than proportion of krodh patients after treatment.

\section{This shows that there is significant effect of treatment}

This proves that at $95 \%$ level of confidence saura-sukta pathan is responsible for lowering krodha as one of the symptom in all mild,moderate and severe grade primary hypertension.

\section{Kamp}

$\mathrm{H}_{0}$ : There is no difference in the proportion of swed patients before and after treatment

$\mathrm{H}_{1}$ :-Praportion of swed patient before treatment is more than proportoion of swed patients after treatment.

i.e. $\mathrm{H}_{0}: \mathrm{P} 1=\mathrm{p} 2$ against an alternative

$\mathrm{H}_{1}: \mathrm{P} 1>\mathrm{p} 2$

Here $P_{1}=12 / 50=0.24$ and and $P_{2}=3 / 50=0.06$ and hence

$\mathrm{Q}_{1}=0.76$ and $\mathrm{Q}_{2}=0.94$

Thus $Z_{\text {calculated }}=2.605$ and $Z_{\text {table }}=1.64$

Since $\mathrm{Z}_{\text {calculated }}>\mathrm{Z}_{\text {table }}$ we reject null hypothesis $\mathrm{H}_{0}$ at $0.5 \%$ level of significance. treatment.

Hence the proportion ofkamp patients before treatment are greater than proportion of kamp patients after

This shows that there is significant effect of treatment. This shows that at $95 \%$ level of confidence saura sukta pathan is responsible for lowering kamp as one of the symptom in all mild, moderate and severe grade hypertension.

\section{I)Shirashula}

$\mathrm{H}_{0}$ : There is no difference in the proportion of shirashula patients before and after treatment. treatment.

$\mathrm{H}_{1}$ :-Proportion of shirashula patient before treatment is more than proportion of shirashula patients after

i.e. $\mathrm{H}_{0}: \mathrm{P} 1=\mathrm{p} 2$ against an alternative

$\mathrm{H}_{1}: \mathrm{P} 1>\mathrm{p} 2$

Here $\mathrm{P}_{1}=34 / 50=0.68$ and and $\mathrm{P}_{2}=3 / 50=0.06$ and hence

$\mathrm{Q}_{1}=0.32$ and $\mathrm{Q}_{2}=0.88$

Thus $Z_{\text {calculated }}=2.66$ and $Z_{\text {table }}=1.64$

Since $\mathrm{Z}_{\text {calculated }}>\mathrm{Z}_{\text {table }}$ we reject null hypothesis $\mathrm{H}_{0}$ at $0.5 \%$ level of significance

Hence the proportion of shirashul patients before treatment is greater than proportion of shirashula patients after treatment. This shows that there is significant effect of treatment.

This shows that at $95 \%$ level of confidence saura sukta pathan is responsible for lowering intensity and frequency of shirashula in all mild, moderate and severe hypertension.

\section{DISCUSSION}

Hriday is organ in the body which is the main functional organ of many stoats in the body such as pranavah, rasavah, srotas and body entities such as vyan vayu, sadhak pitta and avalambak kapha.

When there is any pathology of hriday,or heart,the fuctions of these srotas get hampered and it get reflected as symptoms such as dizziness, syncope, burning sensetions, excessive sweating, anxiety.

Heart is a organ which is responsible for blood circulation and thus provides essential nutrients to each and every cell of the body. It is 'chetanasthanam 'or the site for the liveliness.

Sun is the source of energy and nutrition in the universe. Mantra represents mystical energy encased in sound structure .Every mantra contains power within its vibrations.and continous chanting of these mantras allows its energy to flow through the human body and act as a tool for maintaining homeostatic condition.

Chanting of the mantra from rugveda has proved effective in lowering the symptoms of excessive 
swed and krodhs, kamp and shirashula in mild, moderate and severe grade hypertension.

\section{CONCLUSION}

This proves that at $95 \%$ level of confidence saura-sukta pathan is responsible for lowering swedpravartan, as one of the symptom in all mild,moderate and severe grade primary hypertension.

\section{REFERENCES}

1. Ayurved dipika vyakhya. (2004). By Chakrapani on, charak samhita by acharya charak, sutrasthanam, chapter11, verse no 54, Choukhamba publications, Varanasi, 2004 edition.

2. Ayurved dipika vyakhya. (2004). By Chakrapani on, charak samhita by Acharya charak, sutrasthanam, chapter11, verse no 54, Choukhamba, 11(54) publications, Varanasi, 2004 edition.
3. Ayurved dipika vyakhya. (2004). By Chakrapani on, charak samhita by Acharya charak, vimansthanam, chapter8, verse no 87, Choukhamba publications, Varanasi, 2004 edition.

4. Ayurved dipika vyakhya. (2004). By Chakrapani on, charak samhita by acharya charak, sutrasthanam, verse no 54, Choukhamba publications, Varanasi, 2004 edition.

5. Editor, J. (2015). Alastair Innes, Devidson's essentials of Medicine, pg no 244, Elsevier Health Sciences, 17-Mar-2015 -

6. Nibandhasangraha vyakhya by Dalhan. (2007). On Sushrut samhita by acharya sushruta, uttartantra, chapter 43 , verse no 5 , chaukhamba publication, Varanasi, edition.

7. Nibandhasangraha vyakhya by Dalhan. (2007). On Sushrut samhita by Acharya sushruta, uttartantra, chapter 43, verse no 7, chaukhamba publication, Varanasi, edition 2007, 43(7). 